\title{
УСПІШНІСТЬ ПРИРОДНОГО ПОНОВЛЕННЯ ДЕРЕВНИХ ПОРІД НА ВІТРОВАЛЬНИХ ДІЛЯНКАХ В УКРАЇНСЬКИХ КАРПАТАХ
}

Досліджено процес природного поновлення деревних порід на 42 вітровальних ділянках в Українських Карпатах, які розташовані на території 12 державних лісогосподарських підприємств та установ природно-заповідного фонду України у 15 типах лісу. Проаналізовано видовий склад і частоту трапляння самосіву та підросту окремих деревних порід на досліджених вітровальних ділянках: на пробних площах переважає ялина європейська, частка якої становить 23,7\% від загальної кількості самосіву і підросту, бук лісовий $(21,1 \%)$, ялиця біла $(13,5 \%)$ та клен-явір $(11,3 \%)$. Найрідше трапляється підріст дуба звичайного $(0,03 \%)$, дуба червоного $(0,1 \%)$, липи серцелистої $(0,2 \%)$, черешні $(0,3 \%)$, сосни звичайної $(0,4 \%)$, в'яза шорсткого $(0,8 \%)$ та клена гостролистого $(0,8 \%)$. На 24 досліджених вітровальних ділянках Українських Карпат виявлено добре природне поновлення деревних порід, на вісьмох - задовільне, на дев'ятьох - недостатнє і лише на одній - незадовільне.

Ключові слова: лісознавство; природне поновлення; вітровальні ділянки; корінні деревостани; наближене до природи лісівництво; Українські Карпати.

Вступ. Важливою особливістю лісових екосистем $\epsilon$ їх здатність до самовідновлення і саморегулювання. Ключову роль у цих процесах відіграє природне поновлення деревних порід. Тому вивчення особливостей природного поновлення деревостанів має важливе практичне і теоретичне значення.

Природне поновлення деревних порід в Українських Карпатах у різний час досліджувало багато науковців (Brodovych et al., 2013; Hnidenko, 1997; Golubetc, 1978; Holubchak, 2008; Gorshenin, 1957, 1972; Kramarets \& Krynytskyi, 2008; Krynytskyi et al., 1998; Krinitckii \& Savich, 1973, 1998; Lukashchuk, 2007, 2008; Molotkov et al., 1971; Parpan, 1994; Ravliuk, 2009; Saban, 1982, 1988; Stoiko, 2009; Shparyk et al., 2008; IUsypovych, 1993). Однак ці науковці не вивчали процес природного поновлення деревних порід на вітровальних ділянках у різних регіонах Українських Карпат.

Для достовірного прогнозування розвитку лісових угруповань на вітровальних ділянках в Українських Карпатах і наукового обгрунтування лісогосподарських заходів у молодих післявітровальних деревостанах потрібно досконало вивчити основні тенденції лісовідновного процесу та встановити провідні фактори, що на нього впливають.

Об'єкт дослідження - вітровальні ділянки в лісах Українських Карпат.

Предмет дослідження - методи та засоби природного поновлення деревних порід на вітровальних ділянках в Українських Карпатах.

Мета роботи полягає у дослідженні процесу при- родного поновлення деревних порід на вітровальних ділянках різного віку у переважаючих типах лісу на території Українських Карпат.

Програма проведення експериментальних робіт передбачала вивчення видового складу, кількості та частоти трапляння самосіву і підросту деревних порід на вітровальних ділянках.

Методика та об̆'єкти дослідження. Для оцінки успішності природного поновлення деревних порід на вітровальних ділянках в Українських Карпатах застосовували шкалу проф. М. М. Горшеніна (Gorshenin \& Shvidenko, 1977). Окрім цього ми заміряли висоту самосіву i підросту та розподіляли його на такі групи висот: до $20 \mathrm{~cm}, 21-70$ см, $71-130$ см, $131-200$ см, 201-300 см та понад 300 см.

Для кожної з пробних площ визначали висоту над рівнем моря, стрімкість та експозицію схилу, рік вітровалу, площу ділянки, тип лісу і давали характеристику сусідніх насаджень.

В основу досліджень процесу природного поновлення деревних порід на вітровальних ділянках і формування молодих деревостанів покладено метод порівняльної екології (Vorobev, 1967; Pohrebniak, 1968). Тип лісу на вітровальній ділянці визначали на засадах лісівничо-екологічної типології Алексеєва-Погребняка-Воробйова $(1967,1968)$ за сукупністю керівних і допоміжних ознак.

Об'єкти досліджень були розташовані у різних регіонах Українських Карпат на території 8 державних лісогосподарських підприємств та 4 установ природнозаповідного фонду України: ДП "Боринське лісове гос-

Інформація про авторів:

Лавний Василь Володимирович, д-р с.-г. наук, доцент, проректор з наукової роботи. Email: lavnyy@gmail.com; https://orcid.org/0000-0003-2069-9026

Цитування за ДСтУ: Лавний В. В. Успішність природного поновлення деревних порід на вітровальних ділянках в Українських Карпатах. Науковий вісник НЛтУ України. 2019, т. 29, № 10. С. 61-65.

Citation APA: D Lavnyy, V. V. (2019). Successfulness of tree species natural regeneration on the windthrow areas in the Ukrainian Carpathians. Scientific Bulletin of UNFU, 29(10), 61-65. https://doi.org/10.36930/40291011 
подарство", ДП "Брошнівське лісове господарство", ДП "Вигодське лісове господарство", "Воловецьке лісове господарство", ДП "Міжгірське лісове господарство", ДП "Осмолодське лісове господарство", ДП "Рахівське лісове дослідне господарство", ДП "Хустське лісове дослідне господарство", Карпатський біосферний заповідник, Карпатський НПП, природний заповідник "Горгани" та НПП "Сколівські Бескиди". Всього було закладено 42 пробних площі. Їхнє місце розташування показано на рис. 1.

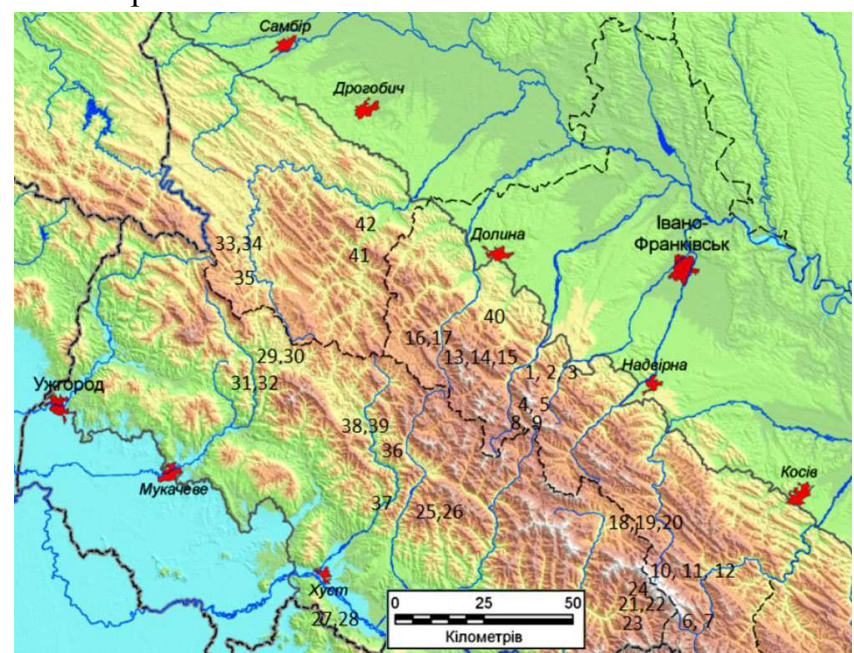

Рис. 1. Місце розташування пробних площ на території Українських Карпат

Площа обстежених вітровальних ділянок змінювалася від 1,1 до 33,0 га. Досліджені вітровальні ділянки знаходилися на різній висоті над рівнем моря (від 475 до 1250 м н.р.м.), на схилах різної експозиції та стрімкості (від 0 до 45 градусів). Пробні площі закладали у переважаючих типах лісу Українських Карпат: вологій буково-ялицевій сусмеречині, вологій буковосмерековій яличині, сирій буково-смерековій суяличині, вологій буково-смерековій суяличині, вологій буково-ялицевій смеречині, вологій чистій бучині, свіжій грабовій бучині, вологій ялицевій бучині, вологій грабовій субучині, свіжій чистій бучині, вологій смереково-ялицевій бучині, вологій чистій субучині, вологій чистій сусмеречині, вологій ялицевій сусмеречині та вологому чистосмерековому суборі.

Результати дослідження. За результатами досліджень встановлено, що між окремими вітровальними ділянками існує значна відмінність за кількістю та видовим складом самосіву і підросту. Зокрема, його чисельність змінювалася від 1501 до 72792 шт./га. У середньому на одній вітровальній ділянці було 17231 шт./га молодих дерев. На обстежених ділянках у складі самосіву і підросту загалом зафіксовано 18 видів деревних порід: березу повислу, бук лісовий, вербу козячу, горобину звичайну, граб звичайний, в'яз шорсткий, дуб звичайний, дуб червоний, осику, клен гостролистий, кленявір, крушину ламку, липу серцелисту, сосну звичайну, черешню, ялину європейську, ялицю білу і ясен звичайний. На деяких вітровальних ділянках виявлено від трьох до одинадцяти порід.

Проаналізувавши видовий склад самосіву і підросту, з'ясовано, що загалом на всіх пробних площах переважає ялина європейська, частка якої становила 23,7 \% від загальної кількості самосіву і підросту, бук лісовий $(21,1 \%)$, ялиця біла $(13,5 \%)$ та клен-явір $(11,3 \%)$.
Найрідше траплявся підріст дуба звичайного (0,03 \%), дуба червоного $(0,1 \%)$, липи серцелистої $(0,2 \%)$, черешні $(0,3 \%)$, сосни звичайної $(0,4 \%)$, в'яза шорсткого $(0,8 \%)$ та клена гостролистого $(0,8 \%)$.

Дослідження показали, що на більшості вітровальних ділянок Українських Карпат серед самосіву і підросту поряд з породами-піонерами значну кількість становлять і головні породи, що дасть змогу в майбутньому $з$ допомогою відповідних лісогосподарських заходів сформувати корінні деревостани відповідно до конкретних типів лісу. Загалом виявилося, що серед типотвірних порід ялина та ялиця переважають у складі самосіву і підросту на північно-східному макросхилі, а бук лісовий - на південно-західному макросхилі Українських Карпат.

Характер розподілу підросту деревних порід на вітровальних ділянках репрезентує показник частоти їх трапляння - виражене у відсотках відношення кількості облікових площадок із самосівом і підростом певної породи до загальної кількості облікових площадок, закладених на ділянці.

За результатами наших досліджень встановлено, що природне поновлення деревних порід на пробних площах відзначається нерівномірним поширенням по площі. Найбільше трапляння на вітровальних ділянках північно-східного макросхилу Українських Карпат має ялина європейська, яку зафіксовано на всіх 26-ти пробних площах цього макросхилу. Частота іï трапляння змінювалася від 3,7 до 93,1 \%. Часто траплялися і горобина звичайна, ялиця біла, бук лісовий, клен-явір, береза повисла, верба козяча та осика. Найрідше на вітровальних ділянках траплявся самосів і підріст дуба червоного та клена гостролистого (лише на одній пробній площі) і сосни звичайної та дуба звичайного (на двох пробних площах). Зазвичай найбільша кількість самосіву і підросту деревних порід спостерігається на окраїнах вітровальних ділянок біля стін прилеглих ростучих деревостанів. Зі збільшенням цієї відстані природне поновлення деревних порід погіршується i найменшу кількість самосіву та підросту фіксували посередині вітровальних ділянок.

На південно-західному макросхилі Українських Карпат у складі самосіву і підросту на обстежених вітровальних ділянках зафіксовано 15 деревних порід. 3 них тільки бук лісовий траплявся на всіх 16 пробних площах. Клен-явір зростав на 15 пробних площах, верба козяча - на 14 пробних площах, смерека і ялиця - на 10 пробних площах. Найрідше траплялися липа дрібнолиста (на трьох пробних площах) та дуб червоний - на двох пробних площах.

Оцінка успішності природного поновлення деревних порід показала, що серед 42 досліджених вітровальних ділянок Українських Карпат на 24 з них спостерігалося добре природне поновлення деревних порід, на вісьмох - задовільне, на дев'ятьох - недостатнє і лише на одній - незадовільне.

Порівняння успішності природного поновлення деревних порід на північно-східному та південно-західному макросхилах Українських Карпат показало, що загалом воно $є$ кращим на південно-західному макросхилі там в середньому виявлено 23448 шт./га самосіву і підросту, а на північно-східному макросхилі - 13394 шт./га. Окрім цього на південно-західному макросхилі не було жодної вітровальної ділянки 3 незадовільним 
природним поновленням, а недостатнє природне поновлення було зафіксовано лише на трьох вітровальних ділянках, тоді як на північно-східному макросхилі на одній вітровальній ділянці спостерігалося незадовільне природне поновлення деревних порід і на шістьох - недостатне.

Як і варто було очікувати, добре природне поновлення деревних порід відбувалося і на вітровальних ділянках у буковому пралісі. Результати наших досліджень показали, що в умовах Угольського природоохоронного науково-дослідного відділення Карпатського біосферного заповідника на обох досліджених вітровальних ділянках у складі самосіву і підросту знову домінує бук лісовий.

Сприятливий вплив на ріст самосіву і підросту деревних порід має вітровальна деревина, що залишається перегнивати у лісі. На мертвій деревині може з'являтися та добре рости самосів смереки та інших порід. Він там має кращий тепловий режим порівняно 3 поверхнею грунту, особливо навесні.

Домішка другорядних деревних порід на вітровальних ділянках на початковому етапі формування нового деревостану відіграє позитивну роль. Вона разом з головними породами ефективно конкурує із живим надгрунтовим покривом за світло, воду і мінеральні речовини, а опад порід-піонерів сприяє кращій мінералізації підстилки, що загалом підвищує родючість грунту. Супутні породи покращують мікрокліматичні умови на вітровальних ділянках і слугують підгоном для головної породи, що покращує в майбутньому якість молодого деревостану.

Зважаючи на те, що всі господарські заходи в лісах України потрібно здійснювати на лісотипологічній основі, ми заклали пробні площі на вітровальних ділянках у переважаючих типах лісу Українських Карпат для вивчення на них успішності природного поновлення деревних порід. Результати досліджень узагальнено у табл. 1. Як бачимо, найбільше пробних площ (15) було закладено у переважаючому в цьому регіоні за площею типі лісу - вологій буково-ялицевій сусмеречині. У цьому типі лісу було зафіксовано в середньому 10951 шт./га самосіву і підросту, що $є$ нижче від середнього значення зі всіх пробних площ (17231 шт./га).

Табл. 1. Кількість самосіву і підросту деревних порід на вітровальних ділянках залежно від типу лісу (шт./га)

\begin{tabular}{|c|c|c|c|}
\hline Тип лісу & $\begin{array}{c}\text { Загальна кількість } \\
\text { самосіву і підрос- } \\
\text { ту на всіх проб- } \\
\text { них площах }\end{array}$ & $\begin{array}{c}\text { Кількість } \\
\text { побних площ } \\
\text { у типі лісу, } \\
\text { шт. }\end{array}$ & $\begin{array}{c}\text { Середня кіль- } \\
\text { кість самосіву } \\
\text { і підросту }\end{array}$ \\
\hline В $_{3}$-См & 3175 & 1 & 3175 \\
\hline $\mathrm{C}_{3}$-См & 60905 & 3 & 20302 \\
\hline $\mathrm{C}_{3}$-яцСм & 6875 & 2 & 3438 \\
\hline $\mathrm{C}_{3}$-бкяцСм & 161224 & 15 & 10748 \\
\hline $\mathrm{C}_{3}$-Бк & 8060 & 1 & 8060 \\
\hline $\mathrm{C}_{3}$-ГБк & 20671 & 1 & 20671 \\
\hline $\mathrm{C}_{3}$-бксмЯц & 27858 & 1 & 27858 \\
\hline $\mathrm{C}_{4}$-бксмЯц & 43818 & 3 & 14606 \\
\hline $\mathrm{D}_{2}$-Бк & 72792 & 1 & 72792 \\
\hline $\mathrm{D}_{2}$-ГБк & 27475 & 2 & 13738 \\
\hline $\mathrm{D}_{3}$-Бк & 54637 & 2 & 27319 \\
\hline $\mathrm{D}_{3}$-яцБк & 51491 & 2 & 25746 \\
\hline $\mathrm{D}_{3}$-бкяцСм & 55390 & 2 & 27695 \\
\hline $\mathrm{D}_{3}$-бксмЯц & 72708 & 5 & 14542 \\
\hline $\mathrm{D}_{3}$-смяцБк & 53570 & 1 & 53570 \\
\hline Всього & $\mathbf{7 2 3 6 8 4}$ & $\mathbf{4 2}$ & $\mathbf{1 7 2 3 1}$ \\
\hline
\end{tabular}

Науковий вісник НлТУ України, 2019, т. 29, № 10
Найкраще природне поновлення деревних порід виявлено на вітровальних ділянках у букових типах лісу, зокрема, у свіжій чистій бучині, вологій смереково-ялицевій бучині, вологій чистій бучині та у вологій ялицевій бучині. Добре природне поновлення було і в ялицевих типах лісу, а саме у вологій буково-смерековій суяличині, сирій буково-смерековій суяличині та вологій буково-смерековій яличині.

Найменшу кількість самосіву і підросту деревних порід зафіксовано у вологому смерековому суборі 3175 шт./га та у вологій ялицевій сусмеречині 3438 шт./га.

За результатами статистичного аналізу встановлено, що між типом лісу і кількістю самосіву та підросту деревних порід не було тісного кореляційного зв'язку, тобто на процес природного поновлення поряд із типом лісу впливає багато інших факторів.

Для вивчення впливу орографічних факторів на хід природного поновлення деревних порід на вітровальних ділянках Українських Карпат ми закладали пробні площі на різній висоті н.р.м., на схилах різних експозицій та різної стрімкості.

Розподіл кількості самосіву і підросту деревних порід залежно від експозиції схилів наведено у табл. 2 та графічно проілюстровано на рис. 2.

Табл. 2. Кількість самосіву і підросту деревних порід на вітровальних ділянках залежно від експозиції схилу (шт./га)

\begin{tabular}{|c|c|c|c|}
\hline $\begin{array}{c}\text { Експо- } \\
\text { зиція } \\
\text { схилу }\end{array}$ & $\begin{array}{c}\text { Загальна кількість само- } \\
\text { сіву і підросту на всіх } \\
\text { пробних площах }\end{array}$ & $\begin{array}{c}\text { Кількість } \\
\text { пробних площ, } \\
\text { шт. }\end{array}$ & $\begin{array}{c}\text { Середня } \\
\text { кількість } \\
\text { самосіву і } \\
\text { підросту }\end{array}$ \\
\hline рівн. & 43818 & 3 & 14606 \\
\hline Пн & 70631 & 5 & 14126 \\
\hline Пн-Сх & 60215 & 3 & 20072 \\
\hline Сх & 38498 & 4 & 9625 \\
\hline Пд-Сх & 126541 & 5 & 25308 \\
\hline Пд & 138642 & 6 & 23107 \\
\hline Пд-3х & 58391 & 5 & 11678 \\
\hline $3 \mathrm{x}$ & 88835 & 6 & 14806 \\
\hline Пн-3х & 98113 & 5 & 19623 \\
\hline
\end{tabular}

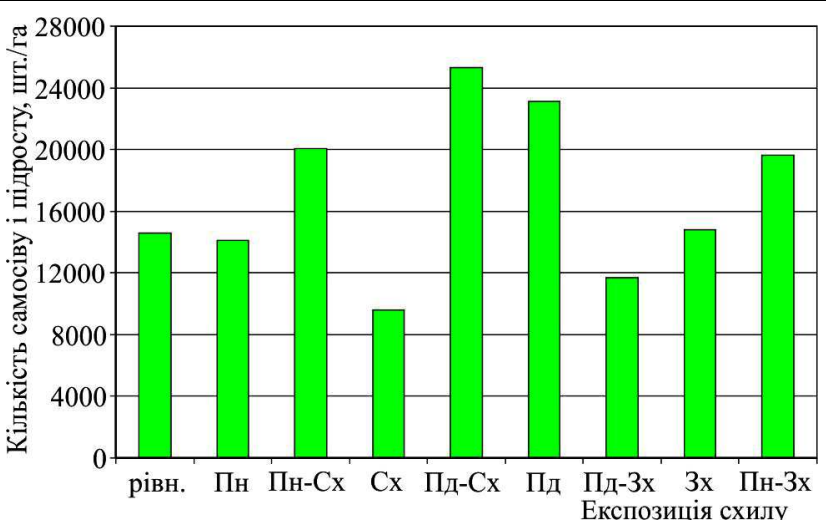

Рис. 2. Розподіл кількості самосіву і підросту деревних порід на вітровальних ділянках залежно від експозиції схилу

3 табл. 2 і рис. 2 бачимо, що найбільшу кількість самосіву і підросту зафіксовано на південно-східних та південних схилах, а найменшу - на східних і південнозахідних схилах. Однак коефіцієнт кореляції між експозицією схилу та кількістю самосіву і підросту становить лише 0,035 , тобто експозиція схилу не має істотного впливу на успішність природного поновлення деревних порід.

Scientific Bulletin of UNFU, 2019, vol. 29, no 10 63 
Розподіл кількості самосіву і підросту деревних порід на вітровальних ділянках Українських Карпат залежно від стрімкості схилу наведено у табл. 3. Найбільше пробних площ було закладено на переважаючих у Карпатах спадистих і стрімких схилах - відповідно 18 і 14 шт. Результати досліджень показали, що стрімкість схилу не має істотного впливу на кількість самосіву та підросту. Коефіцієнт кореляції між стрімкістю схилу та кількістю самосіву і підросту деревних порід становить тільки 0,18 .

Табл. 3. Кількість самосіву і підросту деревних порід на вітровальних ділянках залежно від стрімкості схилу (шт./га) \begin{tabular}{|l|l|l|l|}
\hline Стрімкість Загальна кількість са- Кількість & Середня кіль- \\
\hline
\end{tabular}

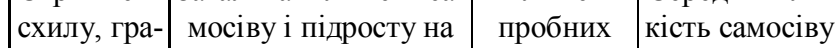

\begin{tabular}{c|c|c|c|}
$\begin{array}{c}\text { дусів } \\
0-10\end{array}$ & 43818 & 3 & 14606 \\
\hline $11-20$ & 256846 & 18 & 14269 \\
\hline $21-30$ & 273547 & 14 & 19539 \\
\hline $31-40$ & 124472 & 6 & 20745 \\
\hline понад 40 & 25001 & 1 & 25001 \\
\hline
\end{tabular}

Також ми проаналізували вплив висоти н.р.м. на хід природного поновлення деревних порід на вітровальних ділянках. Результати досліджень узагальнено у табл. 4.

Табл. 4. Кількість самосіву і підросту деревних порід на вітровальних ділянках залежно від їх висоти н.р.м. (шт./га)

\begin{tabular}{|c|c|c|c|}
\hline $\begin{array}{c}\text { Висота віт- } \\
\text { ровальної ді- } \\
\text { лянки н.р.м., } \\
\text { магальна кількість }\end{array}$ & $\begin{array}{c}\text { сумосіву і підрос- } \\
\text { всіх пробних } \\
\text { площах }\end{array}$ & $\begin{array}{c}\text { Кількість } \\
\text { пробних } \\
\text { пощ у групі } \\
\text { висот, шт. }\end{array}$ & $\begin{array}{c}\text { Середня } \\
\text { кількість са- } \\
\text { мосіву і під- } \\
\text { росту }\end{array}$ \\
\hline до 600 & 132647 & 9 & 14739 \\
\hline $601-800$ & 221391 & 11 & 20126 \\
\hline $801-1000$ & 249794 & 10 & 24979 \\
\hline $1001-1200$ & 107321 & 9 & 11925 \\
\hline понад 1200 & 12531 & 3 & 4177 \\
\hline
\end{tabular}

Виявилося, що найбільша кількість самосіву і підросту зосереджена на вітровальних ділянках, що розташовані на висоті 801-1000 м н. р. м. - у середньому 24979 шт./га та 601-800 м н. р. м. - 20126 шт./га. Найменше самосіву і підросту зафіксовано на вітровальних ділянках, розташованих на висоті понад 1200 м н. p. м. - у середньому лише 4177 шт./га. Між висотою ділянки та кількістю самосіву і підросту деревних порід існує від'ємний слабкий зв'язок, коефіцієнт кореляції становить $-0,126$.

Загалом результати аналізу природного поновлення деревних порід на вітровальних ділянках в Українських Карпатах свідчать, що основні типотвірні деревні породи (бук, ялиця, ялина), маючи високу генеративну здатність, успішно відновлюють лісостани на вітровальних ділянках. Однак процес природного поновлення інколи затягується в часі, а відновлені деревостани потребують покращення їх якості та підвищення продуктивності. Для цього потрібно застосувати низку лісівничих заходів.

Висновки. Між окремими вітровальними ділянками виявлено значну відмінність за кількістю та видовим складом самосіву і підросту. Чисельність підросту змінювалася від 1501 до 72792 шт./га. У середньому на одній вітровальній ділянці було 17231 шт./га молодих дерев. На обстежених ділянках у складі самосіву і підросту загалом зафіксовано 18 видів деревних порід: березу повислу, бук лісовий, вербу козячу, горобину звичайну, граб звичайний, в'яз шорсткий, дуб звичайний, дуб червоний, осику, клен гостролистий, клен-явір, крушину ламку, липу серцелисту, сосну звичайну, черешню, ялину європейську, ялицю білу і ясен звичайний. На деяких вітровальних ділянках виявлено від трьох до одинадцяти порід.

На пробних площах у лісопоновлювальному процесі переважає ялина європейська, частка якої становила 23,7 \% від загальної кількості самосіву і підросту, бук лісовий $(21,1 \%)$, ялиця біла $(13,5 \%)$ та клен-явір $(11,3 \%)$. Найрідше траплявся підріст дуба звичайного $(0,03 \%)$, дуба червоного $(0,1 \%)$, липи серцелистої $(0,2 \%)$, черешні $(0,3 \%)$, сосни звичайної $(0,4 \%)$, в'яза шорсткого $(0,8 \%)$ та клена гостролистого $(0,8 \%)$.

Серед 42 досліджених вітровальних ділянок Українських Карпат на 24 з них встановлено добре природне поновлення деревних порід, на вісьмох - задовільне, на дев'ятьох - недостатне і лише на одній - незадовільне.

Порівняння успішності природного поновлення деревних порід на північно-східному та південно-західному макросхилах показало, що загалом воно є кращим на південно-західному макросхилі Українських Карпат там в середньому спостерігалося 23448 шт./га самосіву і підросту, а на північно-східному - 13394 шт./га.

Загалом на більшості вітровальних ділянок Українських Карпат серед самосіву і підросту значну кількість становлять головні типотвірні породи, що сприятиме формуванню в майбутньому корінних деревостанів відповідно до певних типів лісу.

\section{References}

Brodovych, R. I., Hudyma, V. M., Brodovych, Yu. R., \& Katsuliak, Yu. D. (2013). Pryrodne vidnovlennia holovnykh lisoutvoriuvalnykh porid karpatskoho rehionu ta shliakhy yoho intensyfikatsii. Scientific Bulletin of UNFU, 23(5), 162-168. [In Ukrainian].

Golubetc, M. A. (1978). Elniki Ukrainskikh Karpat. Kyiv: Scientific thought, 264 p. [In Russian].

Gorshenin, N. M. (1957). Metody izucheniia estestvennogo vozobnovleniia i erozii pochv. Nauchnye trudy LLTI, 4, 35-42. [In Russian].

Gorshenin, N. M. (1972). Dinamika estestvennogo vozobnovleniia na uchastkakh raznykh sposobov rubok v gornykh lesakh Karpat. Forestry and Agroforestry, 31, 17-26. [In Russian].

Gorshenin, N. M., \& Shvidenko, A. I. (1977). Lesovodstvo. Lviv: Higher school, 303 p. [In Russian].

Hnidenko, V. I. (1997). Vidnovlennia i formuvannia lisu na vyrubkakh. Uzhhorod: Patent, 123 p. [In Ukrainian].

Holubchak, O. I. (2008). Formuvannia molodykh derevostaniv Gorgan (rezultaty doslidzhennia ta praktychni rekomendatsii). Lviv: NU "Lvivska politekhnika", 40 p. [In Ukrainian].

IUsypovych, I. M. (1993). Typy vyrubok $i$ lisovidnovlennia $v$ Beskydakh (Ukrainski Karpaty). Lviv: LLTI, 107 p. [In Ukrainian].

Kramarets, V. O., \& Krynytskyi, H. T. (2008). Pryrodne ponovlennia v yalynovykh lisostanakh zapovidnoho urochyshcha "Makivka". Proceedings of the Forestry Academy of Sciences of Ukraine, 6, 78-81. [In Ukrainian].

Krinitckii, G. T., \& Savich, I. P. (1973). Sokhrannost samoseva buka i ego sputnikov na lesosekakh raznykh sposobov rubok v Karpatakh. Forestry and Agroforestry, 32, 52-55. [In Russian].

Krynytskyi, H. T., Delehan, I. V., Zemlynskyi, S. M., \& Savych, I. P. (1998). Osoblyvosti formuvannia lisovykh fitotsenoziv na bukovykh zrubakh Ukrainskykh Karpat. Scientific Bulletin of UNFU, 8(9), 26-32. [In Ukrainian].

Lukashchuk, H. B. (2007). Populiatsiina stratehiia vydiv ta yii vplyv na formuvannia roslynnykh uhrupovan na zrubakh Gorgan. Scientific Bulletin of UNFU, 17(7), 76-81. [In Ukrainian]. 
Lukashchuk, H. B. (2008). Napriamy formuvannia maibutnoho derevostanu iz yuvenilnoho potomstva $\mathrm{v}$ riznykh typakh lisu na zrubakh Gorgan. Scientific Bulletin of UNFU, 18(6), 47-51. [In Ukrainian].

Molotkov, P. I., Mamontov, N. I., Gnidenko, V. I., \& Molotkova, N. I (1971). Estestvennoe vozobnovlenie lesov. Uzhhorod: Carpathians, 124 p. [In Russian].

Parpan, V. I. (1994). Struktura, dinamika, ekologicheskie osnovy ratcionalnogo ispolzovaniia bukovykh lesov Karpatskogo regiona Ukrainy. Abstract of doctoral dissertation for biology sciences (03.00.16 - Ecology). Dnipropetrovsk, 42 p. [In Russian].
Ravliuk, I. P. (2009). Osoblyvosti ta stan pryrodnoho vidnovlennia pid nametom yalytsevykh lisiv Karpat. Forestry and Agroforestry, 116, 85-89. [In Ukrainian].

Saban, Ia. A. (1982). Ekologiia gornykh lesov. Moscow: Lesn. promst, 168 p. [In Russian].

Saban, Ia. A. (1988). Produktivnost i vozobnovlenie lesa v gornykh usloviiakh. Lviv: Higher school, 144 p. [In Russian].

Shparyk, Yu. S., Biurhi, A., Kommarmot, B., \& Sukhariuk, D. D. (2008). Dynamika pryrodnoho vidnovlennia bukovoho pralisu. Scientific Bulletin of UNFU, 18(2), 45-51. [In Ukrainian].

V. V. Lavnyy

Ukrainian National Forestry University, Lviv, Ukraine

\section{SUCCESSFULNESS OF TREE SPECIES NATURAL REGENERATION ON THE WINDTHROW AREAS IN THE UKRAINIAN CARPATHIANS}

The process of tree species natural regeneration on 42 windthrow areas, which were located on the territory of 12 State Forest Management Enterprises and Nature Protected Areas in 15 forest types in the Ukrainian Carpathians was investigated. The composition and frequency of the tree species self-seeding and undergrowth occurrence on the investigated windthrow areas were analyzed. The European spruce was the most represented on the sample plots, accounting for $23.7 \%$ of the total number of the selfseeding and undergrowth, beech $-21.1 \%$, silver fir $-13.5 \%$ and sycamore maple $(11.3 \%)$. The least frequently was recorded for undergrowth of pedunculate oak $(0.03 \%)$, red oak $(0.1 \%)$, heart-shaped lime $(0.2 \%)$, wild cherry $(0.3 \%)$, Scots pine $(0.4 \%)$, rough elm $(0.8 \%)$ and Norway maple $(0.8 \%)$. All 24 investigated windthrow areas of the Ukrainian Carpathian showed good natural regeneration of tree species, eight were found to be satisfactory, nine - insufficient and only one - unsatisfactory. The number of self-seeding and undergrowth on one windthrow area ranged from 1,501 to 72,792 pcs./ha. On one windthrow area it was observed from three to eleven tree species. Comparison of the natural regeneration of tree species success on the northeastern and southwestern macro-slopes showed that in general it is better on the southwestern macro-slope of the Ukrainian Carpathians - in average 23448 $\mathrm{pcs}$./ha of self-seeding and undergrowth were observed there, while on the northeastern macro-slope only $13394 \mathrm{pcs}$./ha. Generally, on the windthrow areas among the self-seeding and undergrowth the main tree species accounted a significant share, that will allow in the future with help of the appropriate silvicultural measures to form the primary tree stands.

Keywords: forest ecology; forest types; growth conditions; forestry; close to nature silviculture. 